\title{
Students' Ability to Arrange Mathematical Learning Devices Using Discovery Learning Model in Innovative Learning II Course
}

\author{
P Wijayanti \\ Department of Mathematics \\ Universitas Negeri Surabaya, \\ Ketintang Street, Surabaya 60231 \\ Indonesia \\ pradnyowijayanti@unesa.ac.id
}

\author{
Ismail \\ Department of Mathematics \\ Universitas Negeri Surabaya, \\ Ketintang Street, Surabaya 60231 \\ Indonesia \\ ismail@unesa.ac.id
}

\author{
I Kurniasari \\ Department of Mathematics \\ Universitas Negeri Surabaya, \\ Ketintang Street, Surabaya 60231 \\ Indonesia \\ ikakurniasari@unesa.ac.id
}

\begin{abstract}
Based on mathematics curriculum development in primary and secondary schools, Unesa Mathematics Department through the KKNI curriculum has tried to adjust 2013 curriculum, which is to teach students about learning with scientific and constructivist approach. This is done in the subject of Innovative Learning II through discovery learning chapter. Therefore, this study aims to determine the ability of Mathematics Education students to develop learning devices with discovery learning models in the subjects of Innovative Learning II. This study included qualitative descriptive research. The subject of this research was 25 people of $2016 \mathrm{U}$ class in Mathematics Education Study Program. This study uses Validation Sheet and Task Sheet as instrument. The results of this study are the ability of students to choose mathematical material that is suitable for compiling discovery learning devices in the Innovative Learning II course, which is students generally only be able to explain the basic theoretical, mention, and explain the phase of discovery learning. Nevertheless, in the Innovative Learning II course shows that almost all students have been able to compile a tool for the discovery learning model, because students have demonstrated learning objectives, learning materials, learning steps, and worksheet used.
\end{abstract} model.

Keywords - ability, to develop learning, discovery learning

\section{INTRODUCTION}

The learning process in Primary and Secondary Education (for the implementation of the 2013 Curriculum) is regulated through the Minister of Education and Culture Regulation Number 22 of 2016 about Standard Process, which states the basic concept of the learning process, that students are viewed as subjects who have the ability to actively search, process, construct, and use knowledge. In line with this view, learning must be concerned with opportunities given to students to construct knowledge in their cognitive processes. Furthermore, in order to truly understand and be able to apply knowledge, students need to be encouraged to solve problems, find everything for themselves, and strive to realize their ideas.

Basically, learning is a process of interaction between students and educators by using learning resources in a learning environment. Learning is a process to help students learn well. Maximum learning will lead to successful learning targets. The learning process will run optimally if supported by student learning motivation and teacher creativity. The use of learning models in teaching and learning process can generate new interests and desires, motivation and stimulation of learning activities. The use of learning models will greatly help the effectiveness of the learning process and the delivery of messages and content of the lesson, so that the target of learning can be achieved optimally.

In line with these basic concepts and learning principles, learning process in Curriculum 2013 uses a scientific approach or a scientific process-based approach. Then to strengthen the scientific approach, it is necessary to apply disclosure/research learning (discovery/inquiry learning). In addition to the scientific approach, other learning models can be applied, including discovery learning, project-based learning, problem-based learning, and inquiry learning.

Responding to the curriculum development in secondary schools, the Mathematics Department of FMIPA UNESA through the KKNI Curriculum applied in the Mathematics Education Study Program has tried to innovate and adapt to the demands of the 2013 Curriculum, one of which came the Innovative Learning II course. The course aims to make students understand the scientific approach orienting learning models such as: problem-based learning, project-based learning, inquiry-discovery learning and contextual learning and its application in task-based learning and IT simulation. In the course, students learn about learning theory, learning characteristics and learning steps with these models and develop learning tools that are relevant to these models. Based on the results of the evaluation, it turns out that in Innovative Learning II course many students still have not been unable to choose an equivalent junior/senior high school mathematics material suitable to teach indicators of basic competencies in Main Competence Knowledge and skills through discovery learning.

One important aspect that must be considered by the instructor lecturer in Innovative Learning II is the aspect of the ability of students to develop discovery learning devices, because these abilities must be possessed by students as prospective teachers when they begin to go to school. A good teacher is a teacher who can design learning well, design learning devices, carry out learning with appropriate learning methods or models, and conduct an assessment of the learning implementation. This study focuses on the preparation/design of learning devices using discovery learning which includes: learning plans (RPP), student worksheets (LKPD), assessment sheets, and learning media.

Based on the background that has been stated, the researcher is interested in conducting research by the title "Students' Ability to Arrange Mathematical Learning 
Devices Using Discovery Learning Models in Innovative Learning II Courses". Furthermore, the objective of this study is as follows.

a. Describe the ability of students to choose mathematical material that is suitable for compiling discovery learning devices in Innovative Learning II course.

b. Describe the ability of students in compiling discovery learning for mathematical material devices in Innovative Learning II course.

\section{METHOD}

Based on the objective of the study, namely to describe the ability of students to choose material and compile tools for the discovery learning model, the type of this study included qualitative descriptive research. As for the students compiled in this study is a discovery-based learning tool for junior and/or high school level. Furthermore, the learning tools developed are the Learning Plan (RPP) and discoverybased Student Worksheet (LKPD) developed by students while taking innovative learning II course.

This research was conducted at the Mathematics Department of UNESA. The subjects of this study were all the 2016 U class of Mathematics Education Study Program students who programed the Innovative Learning II course in the 2018/2019 academic year which consisted of 25 people.

\section{RESULTS}

\section{A. The ability of students to choose mathematical material} that is suitable for compiling discovery learning devices in Innovative Learning II course

The ability of students to choose mathematical material to be used in a learning model is very important for achieving learning goals. In this study, the ability of students to choose mathematical material for discovery learning model is viewed from two things, they are the ability of students to explain the characteristics of learning that uses discovery learning models and the ability of students to choose material that fits the Discovery Learning Model uses KI/KD from the 2013 curriculum.

Based on the results of data analysis of student abilities in explaining the characteristics of a learning that uses discovery learning models and data on students' ability to choose material that is in accordance with Discovery Learning Model using KI/KD from curriculum 2013 can be seen in the Table 1.

TABLE 1. VALUE OF STUDENT ABILITY IN CHOOSING MATHEMATICAL MATERIALS FOR DISCOVERY LEARNING MODELS.

\begin{tabular}{|c|c|c|c|c|c|c|c|}
\hline \multirow{2}{*}{ No. } & \multirow{2}{*}{ Components } & \multicolumn{5}{|c|}{ Value } & \multirow{2}{*}{$\begin{array}{l}\text { Subject } \\
\text { Amount }\end{array}$} \\
\hline & & 0 & 1 & 2 & 3 & 4 & \\
\hline 1. & $\begin{array}{l}\text { Students ability in } \\
\text { explaining a learning } \\
\text { which uses discovery } \\
\text { learning model. }\end{array}$ & 8 & 4 & 10 & 2 & 1 & 25 \\
\hline 2. & $\begin{array}{l}\text { Students ability in } \\
\text { choosing material } \\
\text { which suitables with } \\
\text { discovery learning } \\
\text { model by using main } \\
\text { and basic competence } \\
\text { from curriculum } 2013 \text {. }\end{array}$ & & & & & & \\
\hline & VII grade & 0 & 0 & 16 & 7 & 2 & 25 \\
\hline
\end{tabular}

\begin{tabular}{|c|c|c|c|c|c|c|c|}
\hline \multirow{2}{*}{ No. } & \multirow{2}{*}{ Components } & \multicolumn{5}{|c|}{ Value } & \multirow{2}{*}{$\begin{array}{c}\text { Subject } \\
\text { Amount }\end{array}$} \\
\hline & & 0 & 1 & 2 & 3 & 4 & \\
\hline & VIII grade & 0 & 1 & 16 & 6 & 2 & 25 \\
\hline & IX grade & 0 & 0 & 16 & 8 & 1 & 25 \\
\hline & $X$ grade & 0 & 0 & 18 & 7 & 0 & 25 \\
\hline & XI grade & 0 & 0 & 16 & 7 & 2 & 25 \\
\hline & XII grade & 0 & 0 & 17 & 7 & 1 & 25 \\
\hline
\end{tabular}

Based on the Table 1, by looking at the assessment criteria used, then the ability of students to explain the characteristics of a learning that uses the discovery learning model is $1(4 \%)$ student which can explain all indicators including the theoretical foundation, phase, management class, and assessment of discovery learning. There are $2(8 \%)$ students which can explain 3 of the 4 indicators above. 10 (40\%) students which can explain 2 of 4 indicators above. 4 people (16\%) students which can explain 1 of 4 indicators above, and $8(32 \%)$ students cannot explain 4 indicators above.

Based on the Table 1, by looking at the assessment criteria used, the ability of students to choose material that is in accordance with the Discovery Learning Model using main and basic competence (KI/KD) from curriculum 2013 is mostly from students, there are 16 to 18 students or around $68 \%$ students only explain indicators to find concepts, 6 to 8 students or about $28 \%$ of students only explain the outline of learning activities that are in accordance with the steps for the discovery learning model, and only 2 students or about $8 \%$ of students can explain the indicators for find the concepts and steps of learning.

Some mathematical material successfully selected by students for the discovery learning model, among others, found a rectangular circumference formula, namely $K=2 p l$, rectangular area formula, namely $L=p l$, cube volume formula, namely $V=s^{3}$, and the surface formula of the cube, namely $L=6\left(s^{2}\right)$.

\section{B. The ability of students in compiling discovery learning} devices in Innovative Learning II course.

The ability of students to develop discovery learning devices is one of the skills that must be mastered by students as a provision later in teaching. Based on the data that has been obtained, the results of students' abilities in compiling learning devices can be seen in the following table.

\section{TABLE 2. VALUE OF LEARNING PLAN COMPONENTS AND THE} NUMBER OF STUDENTS

\begin{tabular}{|c|c|c|c|c|c|c|c|c|c|}
\hline \multirow{2}{*}{ No. } & \multirow{2}{*}{$\begin{array}{c}\text { Learning Plan } \\
\text { Component }\end{array}$} & \multicolumn{7}{|c|}{ Value } & \multirow[t]{2}{*}{ Amount } \\
\hline & & 4 & 5 & 6 & 7 & 8 & 9 & 10 & \\
\hline \multirow[t]{5}{*}{1.} & \multicolumn{9}{|l|}{ Learning Objectives } \\
\hline & $\begin{array}{l}\text { a. The compatibility of the } \\
\text { objectives with the } \\
\text { achievement indicator of } \\
\text { competence. }\end{array}$ & 1 & 0 & 1 & 8 & 14 & 1 & 0 & 25 \\
\hline & $\begin{array}{l}\text { b. The used operational } \\
\text { verb can be observed and } \\
\text { measured. }\end{array}$ & 0 & 1 & 0 & 7 & 16 & 1 & 0 & 25 \\
\hline & c. Learning objectives & 0 & 0 & 2 & 11 & 12 & 0 & 0 & 25 \\
\hline & $\begin{array}{l}\text { d. Learning objective' } \\
\text { formulation }\end{array}$ & 1 & 6 & 3 & 10 & 5 & 0 & 0 & 25 \\
\hline \multirow[t]{4}{*}{2.} & \multicolumn{9}{|l|}{ Learning Material } \\
\hline & $\begin{array}{l}\text { a. The compatibility of } \\
\text { learning material with } \\
\text { basic competence and } \\
\text { indicators. }\end{array}$ & 1 & 0 & 0 & 14 & 9 & 1 & 0 & 25 \\
\hline & $\begin{array}{l}\text { b. The composition of } \\
\text { learning material }\end{array}$ & 0 & 0 & 1 & 14 & 10 & 0 & 0 & 25 \\
\hline & c. The developed worksheet & 4 & 9 & 6 & 3 & 3 & 0 & 0 & 25 \\
\hline 3. & \multicolumn{9}{|l|}{ Learning Strategy } \\
\hline
\end{tabular}




\begin{tabular}{|c|c|c|c|c|c|c|c|c|c|}
\hline \multirow{2}{*}{ No. } & \multirow{2}{*}{$\begin{array}{c}\text { Learning Plan } \\
\text { Component }\end{array}$} & \multicolumn{7}{|c|}{ Value } & \multirow[t]{2}{*}{ Amount } \\
\hline & & 4 & 5 & 6 & 7 & 8 & 9 & 10 & \\
\hline & $\begin{array}{l}\text { a. Learning model, } \\
\text { approach, and method. }\end{array}$ & 0 & 0 & 2 & 17 & 5 & 1 & 0 & 25 \\
\hline & b. Learning syntax & 0 & 1 & 0 & 15 & 9 & 0 & 0 & 25 \\
\hline & $\begin{array}{l}\text { c. Activity phases of } \\
\text { learning }\end{array}$ & 1 & 0 & 3 & 12 & 9 & 0 & 0 & 25 \\
\hline & d. Applying active learning & 0 & 1 & 0 & 9 & 15 & 0 & 0 & 25 \\
\hline 4. & $\begin{array}{l}\text { The learning media } \\
\text { choosen }\end{array}$ & 0 & 2 & 7 & 9 & 7 & 0 & 0 & 25 \\
\hline 5. & $\begin{array}{l}\text { The learning resource } \\
\text { choosen }\end{array}$ & 1 & 3 & 6 & 11 & 4 & 0 & 0 & 25 \\
\hline \multirow[t]{4}{*}{6.} & \multicolumn{9}{|l|}{ Evaluation } \\
\hline & a. Assessment aspect area & 0 & 1 & 6 & 12 & 6 & 0 & 0 & 25 \\
\hline & $\begin{array}{l}\text { b. The compatibility of } \\
\text { assessment with } \\
\text { objective/indicators. }\end{array}$ & 1 & 0 & 6 & 10 & 8 & 0 & 0 & 25 \\
\hline & c. Assessment component & 0 & 3 & 3 & 16 & 3 & 0 & 0 & 25 \\
\hline
\end{tabular}

Based on the Table 2, by looking at the gradation values between 7 and 10, the results obtained that the ability of students in compiling learning devices for the discovery learning model is there are $23(92 \%)$ students whose learning objectives are in accordance with indicators of competency achievement, 24 (96\%) students have used verbs that can be observed and measured, 24 (96\%) students whose learning objectives include attitudes, knowledge, and skills, 15 (60\%) students that use A (audience), B ( behavior), C (condition), and D (degree) in their learning objectives, 24 (96\%) students choose learning material in accordance with the basic competencies and indicators to be achieved, 24 (96\%) students can systematically arrange learning material in the form of items in order and complete, and 6 (24\%) new students who can arrange worksheet for discovery learning models. There are 23 (92\%) students have been able to write models, approaches, and learning methods in full and in accordance with basic competence, the characteristics of the material taught, and student characteristics, 24 (96\%) students have written the stages of learning activities with complete introduction, core, and concluding, 24 (96\%) students have implemented learning steps that reflect active learning, $16(64 \%)$ students have been able to choose learning media in accordance with learning objectives, learning materials, class conditions, and attention to safety, and 15 $(60 \%)$ students have been able to choose learning resources completely. There are $18(72 \%)$ students have been able to make a complete assessment for all aspects of attitudes, knowledge and skills, 18 (72\%) students have compiled an assessment in accordance with all indicators, and $19(76 \%)$ students already complete in compiling assessments that include grids, tests, solutions, and the scoring rubric.

\section{DISCUSSION}

Based on the results of the data analysis it was found that the ability of students to explain the characteristics of a learning using the discovery learning model can only explain $50 \%$ of all existing features, they are explaining the theoretical basis of discovery learning, mention and explain the phase of discovery learning, explain the management of classes from discovery learning, and explain the assessment in discovery learning. This is because students only understand the steps in the discovery learning model without understand how the background of the learning model is created. If students can understand the philosophy and historical background of learning model, students can easily determine when they can use discovery learning model to teach a material.

Furthermore, the ability of students to choose material that is accordance to the Learning Model of Discovery using basic and main competence from curriculum 2013 is most students only be able to explain one of 2 indicators, they are explaining indicators to find concepts and explain the outline of learning activities in accordance with steps for the discovery learning model. In general, students have been able to explain why the selected material is suitable for the discovery learning model by explaining several parts that can be used for the steps in discovery learning. For example, students can explain what kind of stimulus will be used in the material and then what kind of problem statement that can be arranged in the material. For example, to construct the concept that the size of circumference angle is twice the size of the center angle.

To answer the second research objective, based on the analysis of the data, it was obtained that almost all students were able to compile learning tools because in the device it was found that the learning objectives have accordance with the achievement indicators of competence, used verbs that can be observed and measured, the learning objectives contain attitudes, knowledge, and skills and include $\mathrm{A}$ (audience), B (behavior), C (condition), and D (degree), the selection of learning materials is accordance with the basic competence and indicators to be achieved, can compile the learning material systematically in the form of sequential and complete items, can compile worksheet for discovery learning models, have been able to write models, approaches, and learning methods completely and accordance with the basic competence, the characteristics of the material taught and characteristics of students, have written the stages of learning activities completely including introduction, main, and closing, have implemented learning steps that reflect active learning, have been able to choose learning media according to learning objectives, learning materials, class conditions, and pay attention to safety, have been able to choose learning resources completely, have been able to make a complete assessment for all aspects of attitude, knowledge, and skills, have compiled assessments accordance with all indicators, and have prepared assessments that include grids, tests, answer keys, and scoring rubrics completely. Based on the results of the worksheet made by the students, it turns out that not all of them have fulfilled the worksheet requirements to construct a concept. This is due to the fact that students do not have experience in teaching so students have difficulty in compiling the worksheet.

\section{CONCLUSION}

The ability of students to choose mathematical material that is suitable for composing discovery learning devices in Innovative Learning II course is generally only able to explain the theoretical basis of discovery learning, mention, and explain the phase of discovery learning. Furthermore, most students have been able to choose material that is accordance with the Discovery Learning Model using main and basic competence from the 2013 curriculum which is accompanied by an explanation of the reasons. And then, the ability of students in compiling discovery learning devices in 
the Innovative Learning II course indicate that almost all students have been able to compile tools for the discovery learning model, because students have already demonstrated learning objectives, learning materials, learning steps, and worksheets used.

\section{ACKNOWLEDGMENT}

I thank the members of Mathematics and Natural Sciences Faculty, Universitas Negeri Surabaya for all supports, including the funding.

\section{REFERENCES}

[1] R.W. Dahar, Teori-Teori Belajar, Jakarta: Erlangga, 1991
[2] R. Heinich, M. Molenda, J. D. Russell, and S. Smaldino, Instruction Media and Technologies for Learning, New Jersey: Merrill, Prentice Hall, 1999.

[3] A. Majid, Perencanaan Pembelajaran, Bandung: PT. Remaja Rosdakarya, 2008

[4] Merril Physical Science, Teacher Resource Guide, New York: Glencoe MacMillan/McGraw Hill, 1995.

[5] M. Ibrahim, Dasar-Dasar Proses Belajar Mengajar, Surabaya: Unesa University Press. 2010.

[6] M. Nur, Media Pengajaran dan Teknologi untuk Pembelajaran, 2000, unpublished.

[7] M. Syah, Psikologi Pendidikan Suatu Pendekatan Baru, Bandung: PT Remaja Rosdakarya, 1996

[8] Z. K. Prasetyo, Pengembangan Perangkat Pembelajaran Sains Terpadu Untuk Meningkatkan Kognitif, Keterampilan Proses, Kreativitas serta Menerapkan Konsep Ilmiah Peserta Didik SMP, Program Pascasarjana UNY, 2011, unpublished.

[9] Kementerian Pendidikan dan Kebudayaan, Materi Pelatihan Guru Implementasi Kurikulum 2013, Jakarta: Kemendikbud, 2016. 